\title{
Determination of Effective Mutation Dose on Walnut (Juglans regia L. cv. Chandler) Budwoods
}

\section{Sinem SANLI ${ }^{1}$, Zeynel DALKILIÇ ${ }^{* 1} \mathbb{D}$}

\author{
${ }^{1}$ Aydın Adnan Menderes Üniversitesi Ziraat Fakültesi Bahçe Bitkileri Bölümü Güney Yerleşke 09100 AYDIN
}

Abstract: Walnut (Juglans regia L., $2 n=2 x=32$, Juglandaceae) is a deciduous temperate fruit species with an increasing economic importance and health benefits. The effective mutation dose (EMD) was not determined for 'Chandler' budwoods. The objective of this study was to determine the radiosensitivity of walnut budwoods to cobalt-60 gamma ray. One-year-old budwoods of 'Chandler' walnut cultivar carrying 4-5 buds in $20 \mathrm{~cm}$ in length were irradiated with cobalt-60. The gamma irradiation and chip budding were performed three different times. The budwoods were irradiated (1) with 0 , 10, 20, 30, 40, 50, 60, 70, 80, 90, 100 Gy gamma doses on Apr 2017, (2) with 0, 20, 25, 30, 35, 40 Gy gamma doses on Sep 2017, and (3) with only 42 Gy gamma dose on Apr 2018. Then, gamma irradiated budwoods were chip budded on seedling rootstocks. Mutation 1 Vegetation 1 (M1V1) plants were obtained. The humidity content of the budwoods was determined after gamma irradiation. The bud take ratio, shoot length, and chlorophyll density of M1V1 plants were measured. From the shoot length of the plants, EMD was calculated as $42.1 \mathrm{~Gy}$ after the first irradiation on Apr, 2017, and that was calculated as $20.9 \mathrm{~Gy}$ in the second irradiation on Sep, 2017. The main plant population was obtained by previously calculated $42.1 \mathrm{~Gy}$ dose in the third irradiation on Apr, 2018. The survival rates of budded plants in three irradiation experiments were $21.6 \%$, $54.8 \%$, and $32.0 \%$, respectively. According to the results, the most suitable gamma ray dose is $42.1 \mathrm{~Gy}$.

Keywords: dormant budding, budwood, radiosensitivity, fruit breeding, physical mutagen, gamma irradiation

Ceviz (Juglans regia L. cv. Chandler) Aşı Gözleri Üzerine Etkili Mutasyon Dozunun Belirlenmesi

Öz: Ceviz (Juglans regia L., 2n=2x=32, Juglandaceae), ekonomik önemi ve sağlık açısından faydaları artan, yaprak döken ılıman iklim meyve türüdür. 'Chandler' aşı gözlerinin etkili mutasyon dozu (EMD) henüz belirlenmemiştir. Bu çalışmanın amacı, ceviz aşı gözlerinin kobalt-60 ışınlamasına hassasiyetini belirlemektir. Üzerinde 4-5 aşı gözü bulunan $20 \mathrm{~cm}$ uzunluğundaki 'Chandler' ceviz çeşidi aşı kalemleri kobalt-60 ışınlamasına maruz bırakılmıştır. Üç farklı dönemde gama ışılaması ve yongalı göz aşııı yapılmıştır. Aşı kalemleri (1) Nisan 2017'de 0, 10, 20, 30, 40, 50, 60, 70, 80, 90, 100 Gy gama dozlarına, (2) Eylül 2017'de 0, 20, 25, 30, 35, 40 Gy gama dozlarına ve (3) Nisan 2018 'de 42 Gy gama dozuna tabi tutulmuşlardır. Gama uygulaması yapılan aşı kalemleri çöğür anaçları üzerine yongalı göz aşısı ile aşılanmıştır. Mutasyon 1 Vejetasyon 1 (M1V1) bitkileri elde edilmiştir. Aşı kalemlerinin nem içeriği gama ışılamasından sonra belirlenmiştir. M1V1 bitkilerinin aşı tutma oranı, sürgün boyu ve klorofil yoğunluğu ölçülmüştür. Aşılamadan elde edilen bitkilerin sürgün uzunluklarından, birinci ışınlamadaki $E M D=42.1$ Gy olarak ve ikinci ışınlamadaki $E M D=20.9$ Gy olarak belirlenmiştir. Üçüncü ışınlama döneminde sadece daha önce belirlenen 42.1 Gy dozu uygulanılarak ana populasyon bitkileri oluşturulmuştur. Üç ışılama denemesinden elde edilen aşılı bitki yaşama oranları sırasıyla \%21.6, \%54.8 ve \%32.0. Bu sonuçlara göre, 'Chandler' aşı kalemlerine yapılacak en uygun gama dozu 42.1 Gy'dir.

Anahtar Kelimeler: durgun yongalı göz aşısı, aşı gözü, radyasyon hassasiyeti, meyve ıslahı, fiziksel mutajen, gama ışınlaması

\section{INTRODUCTION}

Juglans regia $(2 n=2 x=32)$ is one of the oldest species in the Juglandaceae family for commercial nut production in the world (Bernard et al., 2018; Karadeniz, 2005; Şen, 2011; Tekintaş et al., 2014). Walnut is preferred by consumers for its health benefits of the omega- 3 fatty acid. The major scion breeding objectives in walnut are late leafing out, lateral fruitfulness, low pistillate flower abscission, high yield and kernel quality, precocity, range of harvest season, and low blight scores. 'Chandler' is one of the most desired walnut cultivar in the world, and this cultivar is highly fruitful on lateral buds. Since it has a very vigorous branching habit under environmental conditions, it needs some pruning, particularly to avoid shoots with a narrow crotch angle (Tulecke and McGranahan, 1994). Tolerance to abiotic and biotic stress factors are the most important rootstock breeding aims in walnuts (Karimi et al., 2018; McGranahan and Leslie, 2012; Vahdati and Lotfi, 2013;
Vahdati et al., 2009). Reducing plant height needs to be evaluated within Juglans spp. germplasm for the ease of cultural practices in high-density plantings (Vahdati et al., 2019).

When sufficient variation does not exist because of improvements in vegetative propagation of walnut (Ebrahimi and Vahdati, 2006; Rezaee et al., 2008), both natural and induced mutations can be used in plant

*Corresponding Author: zdalkilic@adu.edu.tr. This study is produced from the M.Sc. thesis and financially supported by the Scientific Research Project of Aydin Adnan Menderes University (Project Number: ZRF17023).

The submitted date: January 12, 2021

The accepted date: June 7, 2021 
breeding to obtain higher and healthier agricultural products of variant genotypes one or few characteristics differ from their respective progenitors (Jankowicz-Cieslak et al., 2017). Induced mutations can be achieved by either chemical or physical mutagens. Protocols and general considerations for induced mutations in seed and vegetatively propagated plants using gamma rays and EMS (ethyl methane sulfonate), the chemical mutagen, have been previously discussed (Bado et al., 2015; Lamo et al., 2017; Maluszynski et al., 2009; Oladosu et al., 2016; Saito, 2016; Tosri et al., 2019; Ulukapi and Nasircilar, 2015; Yadav et al., 2019). Physical mutagens are comprised of nonionizing (microwave, ultraviolet light, ultra-high hydrostatic pressure, hydrothermal treatment) and ionizing (X-rays, gamma rays, alpha and beta particles, protons and neutrons) radiations (Jain, 2010; Piri et al., 2011). The advantages of using physical as compared to chemical mutagens are the precise dose determination, allowing for a sufficient reproducibility, and a high and uniform penetration in plant tissues, particularly for gamma rays (Piri et al., 2011). While major mutations were $C / G$ to $T / A$ transitions type in the EMS mutants, mutations were $C / G$ to $T / A$ and $A / T$ to $G / C$ transitions, and $A / T$ to $T / A$ transversions in the gamma-ray mutants (Shirasawa et al., 2016). Gamma radiation have provided a high number of useful mutants and is still showing an elevated potential for improving vegetative propagated plants. Gamma rays, since the first report in 1949, are the most used ionizing radiation of the physical mutagens (Suprasanna and Jain, 2017) for plant improvement in the past 70 years (Çelik and Atak, 2017). Seeds, pollen grains, embryogenic calli, mature stem segments, and budwoods can be used for irradiation treatments (Ollitrault and Navarro, 2012; Roose and Williams, 2007a).

As of today, 3364 mutant varieties, approximately $80 \%$ of these obtained by gamma irradiation, have been registered in the mutant variety database (MVD) (Anonymous, 2019). A total of 58 mutant cultivars have been registered belonging to 33 fruit tree species such as apple ('Super Compact'), almond ('Supernova'), cherry ('Aldamla'), fig ('Bol (Abundant)'), grapefruit ('Star Ruby'), lemons ('Alata', 'Eylül', Gülşen', 'Uzun'), mandarins ('Mor', 'Moria', 'NIAB Kinnow', 'Orri', 'Tango'), olives ('Briscola'), oranges ('IAC 2014 Pera'), peaches ('Fuku-ekubo', 'Shimizu Hakutou RS'), pears ('Chaofu 1', 'James Grieve Double Red') and plum ('Spurdente-Ferco') (Anonymous, 2019), a putative Fusarium wilt-resistant banana clone (Jain, 2010). In addition, the lethal dose $50\left(\mathrm{LD}_{50}\right)$ level of radiosensitivity of budwoods in some fruit tree species was determined such as apple (Atay et al, 2018), apricot (Legave and Garcia, 1988), mulberry (Nguyen, 2001), sweet cherry (Saamin and 112
Thompson, 1998), grapefruit (Hearn, 1986), lemon (SpiegelRoy et al., 2007; Uzun et al., 2008), mandarin (Roose and Williams, 2007a; Ballester, 2013; Bermejo et al, 2012; López-García et al., 2015; Roose and Williams, 2007b), and kumquat (Kara-Özbek and Dalkılıç, 2017). However, the radiosensitivity of different plant species and organs can show significant differences under different life-time and ecology (Caplin and Willey, 2018). During 16-h acute exposure to gamma rays, the predicted $L_{50}$ values for Persian walnut (J.regia) and eastern black walnut (J.nigra) were found as 48.0 and $38.3 \mathrm{~Gy}$, respectively. These predicted values were based on interphase chromosome volume (ICV) from vegetatively active growing plants. If they were irradiated during their dormant stage, the $\mathrm{LD}_{50}$ values would be higher. In other words, the plants might be more resistant to gamma rays (Sparrow et al., 1971).

Radiosensitivity of white mulberry (Morus alba) was determined as $40 \mathrm{~Gy}$ (Nguyen, 2001) and that of apricot as 30 Gy (Legave and Garcia, 1988). Saamin and Thompson, (1998) suggested acute gamma irradiation for maximum mutation rate with adequate survival of accessory buds in air at dosages in 'Bing' sweet cherry was approximately $\mathrm{LD}_{50}=27.5-30.0 \mathrm{~Gy}$. Also, recommended gamma ray exposure to Citrus spp. budwoods is between 30 and $50 \mathrm{~Gy}$ for seedlessness induction (Roose and Williams, 2007a). In budwoods of 'Foster' grapefruit were irradiated with 0-110 Gy cesium-137 gamma rays, the $L_{50}$ of the bud survival was $50 \mathrm{~Gy}$ and $90 \mathrm{~Gy}$ grown in the greenhouse and in the nursery, respectively; however, shoot growth was not observed above $50 \mathrm{~Gy}$ in neither of the environment (Hearn, 1986). Budwoods of 'Villafranca' and 'Eureka' lemons were exposed to gamma rays (13.3 $\mathrm{Gy} / \mathrm{min})$, and seedless 'Ayelet' and Galya' mutants were obtained, respectively (Spiegel-Roy et al., 2007). Seedless mutants, namely 'Orri' from 'Orah' mandarin (Vardi et al., 2003a, 2003b) and 'Moria' from 'Murcott' mandarin, were obtained from budwoods irradiation of cobalt-60 gamma rays (3.5 kh). Budwoods of 'Murcott' mandarin were irradiated using with $50 \pm 10 \%$ Gy cobalt-60 source (Bermejo et al., 2012). Budwoods of 'Clemenules' mandarin was exposed to $50-75$ Gy cobalt-60 gamma rays. Only 431(3.6\%) plants gave fruit out of 12,000 buddings (Ballester, 2013). In Ficus carica, 0.0-67.0 Gy cobalt-60 doses were applied to budwoods in 'Sarılop' and 'Bursa Siyahı' in Aydın, Turkey. $\mathrm{LD}_{50}$ was found $50.7 \mathrm{~Gy}$ and 25.3 Gy in 'Sarılop' and 'Bursa Siyahı', respectively (Özen et al., 2017).

From the literature search, no record could be found on the radiosensitivity of 'Chandler' walnut cultivar. Therefore, the objective of this study was to determine the radiosensitivity of 'Chandler' walnut budwoods using gamma ray. The scion breeding aim of this irradiation study was to expect a new 
genotype to improve low fill of the kernel/shell ratio (49\%) of 'Chandler' cultivar. In order to accomplish that the best gamma ray dose used in mutation breeding studies was investigated. This is the first report on radiosensitivity of 'Chandler' budwood to gamma irradiation.

\section{MATERIALS AND METHODS}

One-year-old 'Chandler' ('Pedro' x UC56-224) walnut budwoods were used in the study. 'Chandler' was obtained from a cross made by Serr and Forde in 1963 and was released by the University of California in 1979 (Tulecke and McGranahan, 1994). Irradiation experiments were carried out at three different dates in a cobalt-60 gamma ray cell $(\varnothing 250 \times 220$ mm, 10 L) (Izotop, Ob-Servo Sanguis Co-60 Research Irradiator, Budapest, Hungary) located at Turkish Atomic Energy Authority (TAEK), Sarayköy Nuclear Research and Education Center (SANAEM), Ankara, Turkey. In the first treatment, the dormant budwoods were collected on March 16, 2017 and stored at $+4{ }^{\circ} \mathrm{C}$ until used. The dormant budwoods were irradiated with $0,10,20,30$, and 40 with $36 \mathrm{~Gy} / \mathrm{h}$ speed, and 50,60, 70, 80, 90, and $100 \mathrm{~Gy}$ with 403 $\mathrm{Gy} / \mathrm{h}$ speed cobalt-60 gamma rays on April 27, 2017. In the second treatment, the budwoods were collected from the lignified branches of the same growing season on September 26, 2017. These active season's budwoods were irradiated with $0,20,25,30,35$, and $40 \mathrm{~Gy}$ with $34 \mathrm{~Gy} / \mathrm{h}$ speed on September 27, 2017. Because the bud-take ratio was too low at $50 \mathrm{~Gy}$ and higher gamma doses, $40 \mathrm{~Gy}$ and lower doses was used in the second treatment. In the third treatment, the dormant budwoods were collected during winter pruning period and stored at $+4{ }^{\circ} \mathrm{C}$ until used. Because the calculated EMD was found as $42 \mathrm{~Gy}$, the dormant budwoods were irradiated with only 42 Gy with 31 $\mathrm{Gy} / \mathrm{h}$ speed on April 26, 2018. The budwoods were wrapped in moist towel contained in cryopreservation box while they were carried to and returned back to the gamma irradiation facility in Ankara. All irradiated budwoods were chip-budded on one-year-old J.regia seedling rootstocks in the field nursery one day after irradiation. The mean moisture ratio of the budwoods was recorded after cobalt60 treatment. The budwoods which were not budded were used for the moisture ratio measurement. Five-cm-length pieces of budwoods were dried at $70{ }^{\circ} \mathrm{C}$ for $48 \mathrm{~h}$ in an incubator (JP Selecta, Digiheat, S. A., Spain) located at ADU-AgBioCenter for dry weight measurement. In the first treatment, the rootstocks were cut above the bud union 27 days (on May 25, 2017) after the treatment. The bud take was determined $42^{\text {nd }}$ day on June 9, 2017. Then the number of bud taking was recorded every 10 days until September 15, 2017. In the second treatment, the bud take ratio and shoot length measurement were done eight months (on May 12, 2018) after the treatment. In the third treatment, the bud take ratio was recorded 75 days (on July
SANLI S, DALKILIÇ Z

11, 2018) after the treatment. The M1V1 mutation screening was made by observing survival ratio (\%) at the end of the first growing season in the juvenile nursery plants in 2017 and 2018. Shoot length (cm) was measured with a metal tape measure as a distance from the bud union to the tip of the shoot on September 15, 2017 in the first treatment, on August 25, 2018 in the second treatment, and on August 25, 2018 in the third treatment. Chlorophyll density was recorded as normalized difference vegetation index with PlantPen (NDVI 300, Photon System Instruments, Drasov, Czech Republic) instrument on the upper side of the leaves on August 14 and August 25, 2018 in three experiments. Effective mutation dose (EMD) was calculated using formula as follows: $y=a+b x$ formula where $y$ is $50 \%$ of the shoot length in control ( $0 \mathrm{~Gy}$ ), $a$ is the constant from the regression graph, $b$ is the constant for $x$ values, and $x$ is EMD predicted. Mutation frequency (MF) was calculated using formula as follows (Kunter et al., 2012): MF $(\%)=($ abnormal plants / normal plants $) \times(100 /$ EMD).

\section{RESULTS}

The first irradiation experiment: On April 27, 2017, the mean moisture ratio in budwoods was found $44.4 \%$ being lowest 42.9\% (40 Gy) and highest 45.4\% (10 Gy). In Table 1, the final surviving budded plants were presented in numbers and survival ratios. The bud taking ratio was drastically reduced to $64.6 \%$ (20 Gy) and $7.4 \%$ (50 Gy) on June 29, 2017 while the survival ratio obtained as $62.2 \%$ and $1.8 \%$, respectively, at the end on the growing season. No plants survived above $60 \mathrm{~Gy}$ dose. The shoot length changed from $65.5 \mathrm{~cm}(0 \mathrm{~Gy})$ to $26.0 \mathrm{~cm}$ (50 Gy) at the end of the growing season (Table 1). EMD was calculated as $42.1 \mathrm{~Gy}$. MF values were $0.0 \%$ (0 and $10 \mathrm{~Gy}$ ), 5.9\% (20 Gy), 27.6\% (30 Gy), 27.2\% (40 Gy), and 50.0\% (50 Gy). While chlorophyll density was 4268 in control (0 Gy), it changed from 3175 (50 Gy) to 4763 (10 Gy) in the upper side of the leaves. From this, while gamma dose was increased, chlorophyll density was decreased.

The second irradiation experiment: On Sep 27, 2017, the mean moisture ratio in budwoods was found $57.4 \%$ being lowest 55.0\% (0 Gy) and highest 60.0\% (40 Gy) (Table 1). The bud taking ratio changed from $37.7 \%$ ( $40 \mathrm{~Gy}$ ) to $82.3 \%$ (20 Gy) on Aug 25, 2018. The shoot length changed from $31.6 \mathrm{~cm} \mathrm{(30} \mathrm{Gy)} \mathrm{to} 74.4 \mathrm{~cm}$ (25 Gy) at the end of the growing season. EMD was calculated as 20.9Gy. MF values were $0.0 \%$ (0 Gy), 4.7\% (20 Gy), 7.5\% (25 Gy), 20\% (30 Gy), 25.0\% (35 Gy), and 7.5\% (40 Gy). While chlorophyll density was 3435 in control (0 Gy), it changed from 3097 (30 Gy) to 3756 (40 Gy) in the upper side of the leaves irradiated with gamma rays. From this, except 30 Gy gamma dose was increased chlorophyll density (Table 1). 
Table 1. Effects of gamma ray irradiations in 'Chandler' walnut budwoods

\begin{tabular}{|c|c|c|c|c|c|}
\hline $\begin{array}{l}\text { Irradiation } \\
\text { Application Time } \\
\text { and Dose (Gy) }\end{array}$ & $\begin{array}{l}\text { Chip Budding } \\
\text { with Irradiated } \\
\text { Budwoods (in } \\
\text { numbers) }\end{array}$ & $\begin{array}{c}\text { Moisture Ratio } \\
\text { (\%) }\end{array}$ & $\begin{array}{c}\text { Survival of } \\
\text { Budwoods (in } \\
\text { numbers) (\%) }\end{array}$ & $\begin{array}{l}\text { Shoot Length } \\
(\mathrm{cm})\end{array}$ & $\begin{array}{c}\text { Chlorophyll } \\
\text { Density (upper } \\
\text { side) }\end{array}$ \\
\hline \multicolumn{6}{|l|}{ April 2017} \\
\hline 0 & 52 & 43.4 & $29(55.8)$ & 65.5 & 4268 \\
\hline 10 & 85 & 45.4 & $40(47.0)$ & 54.1 & 4743 \\
\hline 20 & 82 & 45.2 & $51(62.2)$ & 56.9 & 4640 \\
\hline 30 & 103 & 45.1 & $47(45.6)$ & 37.6 & 4363 \\
\hline 40 & 107 & 42.9 & $50(51.4)$ & 55.2 & 4195 \\
\hline 50 & 108 & 45.3 & $2(1.8)$ & 26.0 & 3175 \\
\hline 60 & 110 & 44.7 & $0(0.0)$ & N.A. & N.A. \\
\hline 70 & 99 & 43.4 & $0(0.0)$ & N.A. & N.A. \\
\hline 80 & 96 & 43.7 & $0(0.0)$ & N.A. & N.A. \\
\hline 90 & 104 & 44.3 & $0(0.0)$ & N.A. & N.A. \\
\hline 100 & 91 & 45.0 & $0(0.0)$ & N.A. & N.A. \\
\hline \multicolumn{6}{|l|}{ September 2017} \\
\hline 0 & 38 & 55.0 & $15(39.5)$ & 63.1 & 3435 \\
\hline 20 & 51 & 55.9 & $42(82.3)$ & 60.4 & 3577 \\
\hline 25 & 51 & 58.4 & $40(78.4)$ & 74.4 & 3727 \\
\hline 30 & 50 & 57.4 & $20(40.0)$ & 31.6 & 3097 \\
\hline 35 & 51 & 57.7 & $24(47.0)$ & 57.2 & 3726 \\
\hline 40 & 53 & 60.0 & $20(37.7)$ & 48.1 & 3756 \\
\hline \multicolumn{6}{|l|}{ April 2018} \\
\hline 0 & N.A. & N.A. & N.A. & N.A. & N.A. \\
\hline 42 & 303 & 50.7 & $97(32.0)$ & 27.0 & 5041 \\
\hline
\end{tabular}

"Numbers in parenthesis present the ratios. MF: Mutation frequency. N.A.: not applicable

The third irradiation experiment: On Apr 26, 2018, EMD from the first experiment was used. The mean moisture ratio in budwoods was found $50.7 \%$ using only $42 \mathrm{~Gy}$. The bud taking ratio was $32.0 \%$ ( $42 \mathrm{~Gy}$ ). The survival ratio was $32.0 \%$ and the shoot length was $27.0 \mathrm{~cm}$ at the end of the growing season. MF value was 21.6. Chlorophyll density was 5041 in the upper side of the leaves (Table 1).

\section{DISCUSSION}

The radiosensitivity of different plant organs, namely buds, can show significant differences according to species and ecology (Caplin and Willey, 2018). In our experiments, the dormant 'Chandler' budwoods showed higher EMD values (42.1 Gy) than that in the active budwoods (20.9 Gy). These results could be related to the moisture content in the budwoods during the irradiation application (Kunter et al., 2012). The higher the moisture content of the plant materials is the higher the effectiveness of irradiation. The reason for that water is the most abundant molecule in living cells. Reactive oxygen species (ROS) are the primary radiation products. The indirect action of radiation is responsible for $99.9 \%$ of the protein damage. Gamma 114 irradiation induces stress in the surviving plants. Therefore, it significantly affects physiological and biochemical processes (Lagoda, 2012). Ionizing radiation can involve oxidative stress by producing primary $(\bullet \mathrm{OH}, \mathrm{H} \bullet)$ and secondary $\left(\mathrm{H}_{2} \mathrm{O}_{2}, \mathrm{O}_{2} \bullet^{-}\right)$free radicals (Esnault et al., 2010). While minimum radiosensitivity was observed at intermediate moisture content, increased radiosensitivity was obtained at lower or higher moisture levels rice seeds (Bhattacharya and Joshi, 1977). It was observed that there was marked increase in mutation frequency as the moisture content decreases below $14 \%$ in barley seeds (Mba et al., 2010).

One of the first mutation studies was conducted in walnut seeds in Ukraine (Kudina, 1988), in that study 1-150 Gy (100-15000 R) of gamma rays applied to the walnut seeds. While fast-growing seedlings were obtained from gamma doses below $200 \mathrm{~Gy}$, slow-growing (dwarf) seedlings were observed all, especially higher, doses.

Kudina (1988) reported when the irradiation dose increases, the bud take ratio decreases after a certain dose. 
In our experiments, bud taking ratio was reduced after 40 Gy.

Haploid plants were obtained in 'Hartley', 'Pedro', $Z_{63}$, and $Z_{67}$ whose female flowers were pollinated using 300 and $600 \mathrm{~Gy}$ gamma ray-irradiated pollen of walnut selections $Z_{53}$ and $Z_{30}$ in Iran. Diploid plants were obtained from pollen irradiated at 50 and $150 \mathrm{~Gy}$. The results from molecular data showed parthenogenetic origin of the obtained haploid plants (Sadat Hosseini et al., 2011). A previously predicted $\mathrm{LD}_{50}$ gamma dose of $48.8 \mathrm{~Gy}$ for Persian walnut (Sparrow et al., 1971) is in very close proximity to our findings of 42.1 Gy with dormant budwoods. However, Sparrow et al. (1971) prediction was for actively growing trees. They expected the survival rate would be higher if irradiation was applied in the dormant stage.

Chlorophyll density was reduced on the upper side of the leaves irradiated with $50 \mathrm{~Gy}$ (3175) gamma rays in the first treatment. The reason for that might be the negative effect of irradiation doses (Kunter et al., 2012).

Our possible mutant plants will be observed in the field for any leaf or shoot growth aberrations. Leaf aberrations can be observed in natural plant populations (Babcock, 1915; Pennington and Beineke, 1977) or expected after exposure to irradiation (Opeke and Jacobs, 1973). Around 1900, some small-leaved-oak shape J.californica trees grown from seeds were appeared in California. The chromosome numbers $(2 n=2 x=34)$ were not different than the normal seedlings (Babcock, 1915). In 1976, a leaf mutation was discovered in J.nigra in Indiana, and showed new form of leaf had a large round terminal leaflet $(7 \mathrm{~cm}$ in diameter), indented apex, and small lateral leaflets $(2.0-2.5 \mathrm{~cm}$ in diameter). It was speculated that a single recessive trait could be responsible for this mutation in both above observations (Pennington and Beineke, 1977).

In conclusion, recommended cobalt-60 doses for 'Chandler' budwoods are $42.1 \mathrm{~Gy}$ for dormant budwoods and $20.9 \mathrm{~Gy}$ for the same year's lignified budwoods. Above mentioned gamma rays in 'Chandler' budwood can be used in mutation breeding applications to obtain a new cultivar which has higher than $49 \%$ fill of the kernel/shell ratio. The results obtained from this first report on EMD of 'Chandler' budwood to gamma irradiation might open avenues to other chemical and physical mutation studies in walnut.

\section{ACKNOWLEDGEMENTS}

We thank Dr. Burak Kunter and Prof. Dr. Kourosh Vahdati for sharing their expertise during the course of the experiments. ADU-AgBioCenter was acknowledged for allowing us to conduct a part of this work.

\section{REFERENCES}

Anonymous (2019) FAO/IAEA Food and Agriculture Organisation/International Atomic Energy Agency, Vienna. https://mvd.iaea.org/\#!Search(Erişimtarihi: 12/01/2021).
Atay AN, Kunter B, Atay E, Kantoğlu KY, Kaplan N (2018) Radiosensitivity and Preliminary Results in Mutation Breeding of 'Amasya' Apple Cultivar. In: IAEA (ed.), The International Symposium on Plant Mutation Breeding and Biotechnology of FAO, 27-31 August 2018, Vienna, IAEA-CN-263-3.

Babcock EB (1915) Walnut Mutant Investigation. Proceedings of the National Academy of Sciences 1: 535-537.

Bado S, Forster BP, Nielen S, Ali AM, Lagoda PJL, Till BJ, Laimer M (2015) Plant Mutation Breeding Current Progress and Future Assessment. Plant Breeding Reviews 39: 23-87.

Ballester AM (2013) Evaluación y preselección de mutantesdemaduración tardíaobtenidos por irradiación de mandarina Clementina (Citrus clementina Hort. ex Tanaka). MásterTesis, Universidad Politécnica de Valencia, Valencia.

Bermejo A, Pardo J, Cano A (2012) Murcott Seedless: Influence of Gamma Irradiation on Citrus Production and Fruit Quality. Spanish Journal of Agricultural Research 10: 768-777.

Bernard A, Lheureux F, Dirlewanger E (2018) Walnut: Past and Future of Genetic Improvement. Tree Genetics Genomes 14:1-28.

Bhattacharya S, Joshi RK (1977) Factors Modifying Radiation Induced Stimulation in Plants: Pre- irradiation Seed Moisture Content. Rad. Environ. Biophys. 14:47-51.

Caplin N, Willey N (2018) lonizing Radiation, Higher Plants, and Radioprotection: From Acute High Doses to Chronic Low Doses. Frontiers in Plant Science9: 847.

Çelik Ö, Atak Ç (2017) Applications of Ionizing Radiation in Mutation Breeding. In: Maghraby AM (ed.), New Insights on Gamma Rays, InTech Open, London, 111.

Ebrahimi A, Vahdati K (2006) Improved success of Persian walnut grafting under environmentally controlled conditions. International Journal of Fruit Science. 6(4): 3-12.

Esnault M-A, Legue F, Chenal C (2010) lonizing Radiation: Advances in Plant Response. Environmental and Experimental Botany 68: 231-237.

Gulsen O, Uzun A, Pala H, Canihos E, Kafa G (2007) Development of Seedless and Mal Secco Tolerant Mutant Lemons through Budwood Irradiation. Scientia Horticulturae 112: 184-190.

Hearn CJ (1986) Development of Seedless Grapefruit Cultivars through Budwood Irradiation. Journal of the American Society for Horticultural Science 111: 304306.

Jain SM (2010) Mutagenesis in Crop Improvement under the Climate Change. Romanian Biotechnological Letters 15: 88-106.

Jankowicz-Cieslak J, Mba C, Till BJ (2017) Mutagenesis for Crop Breeding and Functional Genomics. In: Jankowicz-Cieslak J, Tai TH, KumlehnJ, Till BJ (eds.), Biotechnologies for Plant Mutation Breeding, FAO/IAEA, Springer, Switzerland, 3-18. 
Karadeniz T (2005) Relationships Between Graft Success and Climatic Values in Walnut (Juglans regia L.). Journal of Central European Agriculture 6(4): 631-634.

Kara-Özbek C, Dalkılıç Z (2017) Effects of Mycorrhiza and Vermicompost on the Growth of Trifoliate Orange Seedlings, and Determination of Tolerance of Nagami Kumquat Budwoods to Cobalt-60 Irradiation and Identification of Different Genotypes with RAPD Markers. ADU Journal of the Faculty of Agriculture14:1-7.

Karimi S, Karami H, Mokhtassi-Bidgoli A, Tavallali V, Vahdati K (2018) Inducing Drought Tolerance in Greenhouse Grown Juglans regia by Imposing Controlled Salt Stress: The Role of Osmotic Adjustment. Scientia Horticulturae 239: 181-192.

Kudina GA (1988) Walnut Mutation Breeding. Mutation Breeding Newsletter 34:24.

Kunter B, Bas M, Kantoglu Y, Burak M (2012) Mutation Breeding of Sweet Cherry (Prunus avium L.) var. 0900 Ziraat. In: Shu QY, Forster BP, Nakagawa H, (eds.), Plant Mutation Breeding and Biotechnology, CABI, Wallingford, 453-459.

Lagoda PJL (2012) Effects of Radiation on Living Cells and Plants. In: Shu QY, Forster BP, Nakagawa $H$, (eds.), Plant Mutation Breeding and Biotechnology, CABI, Wallingford, 123-134.

Lamo K, Bhat DJ, Kour K, Singh Solanki SP (2017) Mutation Studies in Fruit Crops: A Review. International Journal of Current Microbiology and Applied Science 6: 36203633.

Legave JM, Garcia G (1988) Radiosensibilité de Rameaux Greffons d'Abricotier Exposés à un Rayonnement Gamma Aigu et Observation en Pépinière d'une Deuxième Génération Végétative de Bourgeons Irradiés. Agronomie 8: 55-59.

López-García A, Terol J, Tadeo FR, Herrero-Ortega A, Ibañez V, Talón M (2015) Three New Cultivars of Clementine: 'Clemenverd', 'Nero' and 'Neufina'. Acta Horticulturae 1065: 239-243.

Maluszynski M, Szarejko I, Bhatia CR, Nichterlein K, Lagoda PJL (2009) Methodologies for Generating Variability Part 4: Mutation Techniques. In: Ceccarelli S, Guimarães EP, Weltzien E (eds.), Plant Breeding and Farmer Participation, FAO, Rome, 159-194.

Mba C, Afza R, Bado S, Jain SM (2010) Induced Mutagenesis in Plants Using Physical and Chemical Agents. In: Davey MR, Anthony P (eds.), Plant Cell Culture: Essential Methods, John Wiley \& Sons, Ltd., Chichester, UK, 111-130.

McGranahan G, Leslie C (2012) Walnut. In: Badenes ML, Byrne DH (eds.), Fruit Breeding, Springer, London, 827-846.

Nguyen VV (2001) Induction of Mutation on Mulberry (Morus alba L.) by Using In Vitro Techniques in Combination with Gamma Irradiation. JAERIConference3: 160-165.
Oladosu Y, Rafii MY, Abdullah N, Hussin G, Ramli A, Rahim HA, Miah G, Usman M (2016) Principle and Application of Plant Mutagenesis in Crop Improvement: A Review. Biotechnology \& Biotechnological Equipment 30: 1-16.

Ollitrault P, Navarro L (2012) Citrus. In: Badenes ML, Byrne DH (eds.), Fruit Breeding, Springer, London, 623-662.

Opeke LK, Jacobs VJ (1973) Mutation Breeding in Cacao (Theobroma cacao L.). In: FAO/IAEA (ed.), Panel on Mutation Breeding of Vegetatively Propagated Perennial Crops IAEA-PL-501/14,11-15 September 1972, Vienna, 137.

Özen M, Kocataş H, Çobanoğlu F, Ertan B, Kösoğlu i, Tan N, Şahin B, Belge A, Konak R, Aksoy U, Gülşen O (2017) Mutation Breeding Studies of Fig. Acta Horticulturae 1173: 93-98.

Pennington AG, Beineke WF (1977) A New Leaf Mutation in Black Walnut (Juglans nigra L.). Proceedings of Indiana Academy of Science 86: 409-412.

Piri I, Babayan M, Tavassoli A, Javaheri M (2011) The use of Gamma Irradiation in Agriculture. African Journal of Microbiology Research 5: 5806-5811.

Rezaee R, Vahdati K, Grigoorian W, Valizadeh M (2008) Walnut grafting success and bleeding rate as affected by different grafting methods and seedling vigor. The Journal of Horticultural Science \& Biotechnology. 83(1):94-99.

Roose ML, Williams E (2007a) Mutation Breeding. In: Citrus Genetics, Breeding and Biotechnology, In: Khan IA, (ed.), CABI, Wallingford, 345-352.

Roose ML, Williams E (2007b) Mandarin Tree Named 'Tango'. USPP17863P3.

Saamin S, Thompson MM (1998) Radiation-Induced Mutations from Accessory Buds of Sweet Cherry, Prunus avium L. CV 'Bing'. Theoretical and Applied Genetics 96: 912-916.

Sadat Hosseini GM, Vahdati K, Lotfi M, Hassani D, Pirvali Biranvand N (2011) Production of Haploids in Persian Walnut through Parthenogenesis Induced by GammaIrradiated Pollen.Journal of the American Society for Horticultural Science 136:198-204.

Saito T (2016) Advances in Japanese Pear Breeding in Japan. Breeding Science 66: 46-59.

Shirasawa K, Hirakawa H, Nunome T, Tabata S,Isobe S (2016) Genome-Wide Survey of Artificial Mutations Induced by Ethyl Methanesulfonate and Gamma Rays in Tomato. Plant Biotechnology Journal 14: 51-60.

Sparrow AH, Schwemmer SS, Bottino PJ (1971) The Effects of External Gamma Radiation from Radioactive Fallout on Plants with Special Reference to Crop Production. Radiation Botany 11: 85-118.

Spiegel-Roy P, Vardi A, Yaniv Y, Fanberstein L, Elhanati A, Carmi N (2007) 'Ayelet' and 'Galya': New Seedless Lemon Cultivars. HortScience 42: 1723-1724.

Suprasanna P, Jain SM (2017) Mutant Resources and Mutagenesis in Crop Plants. Emirates Journal of Food and Agriculture 29: 651-657. 
Şen SM (2011) Ceviz: Yetiştiriciliği, Besin Değeri, Folklorü. 4. Baskı. ÜÇM Yayıncılık. Ankara.

Tekintaş FE, Şen SM, Akça Y, Erdoğan V, Ertürk Ü, Sütyemez M, Dalkılıç Z (2014) Following Walnut Footprints in Turkey. In: Avanzato D (ed), Fallowing Walnut Footprints (Juglans regia L.): Cultivation and Culture, Folklore and History, Traditions and Uses, Scripta Horticulturae, 17: 401-408.

Tosri C, Chusreeaeom K, Limtiyayotin M, Sukin N, Jompuk P (2019) Comparative Effect of High Energy Electron Beam and ${ }^{137}$ Cs Gamma Ray on Survival, Growth and Chlorophyll Content in Curcuma Hybrid 'Laddawan' and Determine Proper Dose for Mutations Breeding. Emirates Journal of Food and Agriculture 31: 321-327.

Tulecke W, McGranahan G (1994) The Walnut Germplasm Collection of the University of California, Davis: A Description of the Collection and A History of the Breeding Program of Eugene F. Serr and Harold I. Forde. Report No. 13. The University of California Genetic Resources Conservation Program, Davis, CA.

Ulukapi K, Nasircilar AG (2015) Developments of Gamma Ray Application on Mutation Breeding Studies in Recent Years. In: AABES (ed.), The International Conference Advances in Agricultural, Biological and Environmental Sciences, 22-23 July, 2015, London, 3134.
Uzun A, Gulsen O, Kafa G, Seday U (2008) 'Alata', 'Gulsen', and 'Uzun' Seedless Lemons and 'Eylul' EarlyMaturing Lemon. HortScience 43: 1920-1921.

Vahdati K, Lotfi N (2013) Abiotic Stress Tolerance in Plants with Emphasizing on Drought and Salinity Stresses in Walnut. In: Vahdati K, Leslie CA (eds.), Abiotic StressPlant Responses and Applications in Agriculture, InTech Open, Rijeka, 307-365.

Vahdati K, Lotfi N, Kholdebarin B, Hasani D, Amiri R (2009) Screening for Drought Tolerant Genotypes of Persian Walnuts (Juglans regia L.) during Seed Germination. HortScience 44: 1815-1819.

Vahdati K, Arab MM, Sarikhani Khorami S,Sadat Hosseini M, Leslie CA, Brown PJ (2019) Advances in Walnut (Juglans regia L.) Breeding Strategies. In: Al-Khayri JM, Jain SM, Johnson DV (eds.), Advances in Plant Breeding Strategies, Vol 4: Nut and Beverage Crops, Springer, Switzerland, 401-472.

Vardi A, Spiegel-Roy P, Frydman-Shani A, Elchanati A, Neumann H (2003a) Citrus Tree Named 'Orri'. USPP13616.

Vardi A, Spiegel-Roy P, Frydman-Shani A, Elchanati A,Neumann H (2003b) Citrus Tree Named 'Moria'. USPP13460.

Yadav A, Singh B, Singh SD (2019) Impact of Gamma Irradiation on Growth, Yield and Physiological Attributes of Maize. Indian Journal of Experimental Biology 57: 116-122. 
